JNE 5 (1) (2019)
UNNES
Journal of Nonformal Education
http://journal.unnes.ac.id/nju/index.php/jne

\title{
The Analysis of Learning Model in Office Administration Training at Semarang Job Training Development Center
}

\author{
Mujiati $^{\bowtie}$, Tri joko Raharjo, Achmad Rifa'i RC \\ Postgraduate Program in Nonformal Education, Universitas Negeri Semarang, Indonesia
}

DOI: http://dx.doi.org/10.15518/jne.v5i1

\begin{abstract}
Articles Info
History Articles:

Received 22 October 2018

Approved 05 December 2018

Published 1 February 2019

\section{Keywords:}

learning model, adult learning, work readines

Abstract

One reason for the high level of secondary and vocational school participation in quality that does not meet the competency standards required by the labor market. The need for new breakthroughs in order to improve the quality of human resources as an effort to prepare students in the world of work. The purpose of this research is to describe and analyze: (1) The learning model that is implemented in the office administration training that refers to the principle of adult training, (2) the readiness of the participants after completing the training. This research uses qualitative approach method. The subject is the section of training, training instructors, FMD team and trainees. Engineering data collection done by observation, interviews, and documentation. Data analysis techniques include the collection of data, data presentation, data reduction and withdrawal of the conclusion. An examination of the validity of the data using triangulation of sources and method. The research results showed that: (1) the model of learning which is implemented in office administration training refers to information processing model, personal model and behavior modification model. Implementation of the three models includes: learning syntax, social systems, reaction principles, support systems, instructional impacts and impact accompaniment. In the implementation of learning model in office administration, the training is based on adult learning principle, (2) participants' readiness is nurtured through job training activities that include 14 competency units, softskills activities, and character building.
\end{abstract}

(C) 2019 PLS PPs UNNES

\footnotetext{
Address correspondence:

Postgraduate Program in Nonformal Education, Universitas Negeri Semarang

Street Kelud, Jl. Kelud Utara III, Petompon Gajahmungkur, Semarang,

Central Java, Indonesia

E-mail: pls213078@gmail.com
}

p-ISSN 2442-532X

e-ISSN 2528-4541 


\section{INTRODUCTION}

According to Indonesian Statistics Agency's (BPS) data, the open unemployment rate in Indonesia is seen from the level of education in the period of August 2017, the TPT for elementary schools (SD) to down by $2.62 \%$, junior high schools (SMP) by $5.54 \%$, secondary schools Top (SMA) amounting to $8.29 \%$, Vocational School (SMK) by $11.41 \%$, Diploma III (D3) by $6.88 \%$, and University $5.18 \%$. Based on the TPT data from the highest level of education that was completed, showed that the number that contributed the most to unemployment was high school and vocational school graduates. This indicates that the existing of job offerings have not been absorbed well by the two groups of education levels. One of the problems lies in the low quality of human resources, is that the work skills possessed are not enough to be used as a stock in looking for work.

The low quality of human resources will be a barrier for the state to be more developed. Therefore, human resources play an important role in every movement of development. As according to Fernandes (2018) which states that: "quality of human resources has a significant and positive effect on workforce competitiveness, higher quality of human resources will therefore result in higher workforce competitiveness".

The results of the study were strengthened with Permenaker No. 11 of 2013 concerning Guidelines for the Implementation of a National Job Training System in the Regions, is that the preparation of human resources that have competitiveness will be able to bring this nation out of employment conditions, which is still colored by the high unemployment, which has an impact on poverty, ignorance, crime and other social problems .As the conditions of global competition are increasingly sharpened, the development of human resources (HR) is a very important effort and is needed to be able to compete in the arena of international competition (Ruhana, 2012). The results of the study from Widodo (2016) state that, to alleviate the problem of human resources in
Indonesia, the transformation of education is a necessity because with this Indonesian human education can be fully implemented. With the implementation of complete human education, education will be able to produce potential nation children and be ready to play an active role in the world community. In this case, the government continuously make new breakthroughs to improve the quality of human resources.

This is realized by the implementation of non-formal education programs in an effort to develop and improve the quality of sustainable human resources which are carried out through integrated training programs with apprenticeship and work entry selection. Training is a part of education that involves the learning process to acquire and improve skills outside the prevailing education system, and is held in a relatively short time with methods that emphasize to practice rather than theory (Kamil, 2012: 4). The training program in this study was held to improve and develop knowledge, skills and attitudes as an effort to prepare learning citizens to enter the workforce. In addition, training is also expected to prepare the learning community concerned physically, mentally and emotionally to enter the workforce.

One of the institutions under the Ministry of Labor and Transmigration that holds a job training is the Employment Training Development Center (BBPLK) Semarang. BBPLK Semarang was established in 1951 until now, which has the mission "Creating a Competent Workforce and Having a High Work Ethic through Job Training, Certificates and Partnerships". Hold on to this mission, BBPLK Semarang carried out various competency-based training programs with regard to Law No. 13 of 2003 concerning employment said that job training is organized and directed to equip, improve and develop work competencies in order to improve the ability, productivity and prosperity of the workforce.

This managed training program is a government-funded program from the State 
Expenditure Budget Funds (APBN). Besides it is being a training place, BBPLK Semarang has also become a Competency Test Place (TUK), which aims to produce competent and certified candidates for workforce and have competitiveness according to the needs of the job market. Those job training was held in order to assist the government to overcome the problem of unemployment in the Semarang and its surrounding and face the challenges of the Asean Economic Community (AEC) which must be prepared by taking into account the needs of the labor market and the business world which refers to work competency standards. BBPLK Semarang carries out various competency-based training programs, one of them is office administration training. The participants who take part in this training are adults. As the target of the training program is adults, consequently it is very important to apply a learning model that refers to the principles of adult learning so that the learning objectives that have been established can be achieved and can produce competent graduates as of they can be absorbed in the labor market.

Knowles in Rifa'i (2009: 21), stated that the involvement of adults in learning activities is the key to success for adult education. Several studies of adults learning models have been conducted, such as (1) the apprenticeship learning model is a learning model of adult education by direct practice activities. By with the application of an apprenticeship learning model in which the learning process refers to the principles of adult learning so as it can prepare the learning citizens to open their own business (Wardani: 2012), (2) Participatory learning model is defined as an effort to involve the citizens in learning activities. The participation of learning citizens is realized in three stages, they are planning, implementing and evaluating learning. By means of the participation of participants in all three activities, the learning objectives can be achieved effectively (Hidayat, 2016), (3) The application of learning models for food entrepreneurship courses through business cooperation and the industrial world is declared good and very effective to be applied and can reduce unemployment. The results of this study found that the components that must exist in the learning model of food entrepreneurial courses fields are: knowledge, work skills and work attitudes (Yuriani, Marwanti, \& Komariah, 2012), (4) E-learning models are effective for improving cognitive adults. The role of intrinsic motivation, metacognition, independent learning, and learning strategies determine the results of adult learning (De Palo, V., Limone, P., Monacis, L., Ceglie, F., \& Sinatra, M, 2018), (5) Participatory andragogical learning models can be implemented effectively and have a positive impact on learning outcomes of citizens learning in Gorontalo City SKB, this model can be used as a reference by other non-formal education units (Polapa, 2015), (6) The effectiveness of the accelerated learning model shows that students actively participate in learning activities, learning outcomes of participants in good learning and they learn faster, better, are able to apply what they learn in class to work on their projects (Ganiron, 2013).

Looking at the above problems and the importance of improving and developing knowledge, skills and attitudes are efforts to prepare learning citizens to enter the workforce. Therefore educators must be able to develop learning models that allow participants to access their own needs, formulate their learning goals, share responsibilities in designing and implementing learning experiences, and assess their own learning programs. This is the same as the opinion of Uno (2009: 57), that adults will be able to learn effectively and efficiently when: needs / interests, situations of life / work, experience, self-concept and individual differences between participants are involved. Therefore, this study will examine the implementation of learning models in office administration training and participant work readiness after completing training.

The purpose of this study is to describe and analyze (1) the implementation of the learning model in office administration 
training (2) participants' work readiness after the completion of the training.

\section{METHODS}

The approach used in this study is a qualitative approach. According to Bungin (2007: 68) social research uses a descriptive qualitative format that aimed to describe, summarize various conditions, various situations, or various phenomena of social reality that exist in the society which is the object of research, and trying to attract that reality as a characteristic, character, traits, models, signs, or descriptions of certain conditions, situations, or phenomena. This qualitative descriptive method that describes the existing phenomena, there will be an understanding of the interpretation and reality and depth meaning of the facts and the existing facts, because the problems in this study are not numbers but describe, elaborate, and illustrate the implementation of the learning model and participant work readiness after training.

Determining the source of data for the interviewed people in this qualitative research was carried out purposively. Purposive is that the sample (a source/ informant) is selected with a particular considerations and objectives. Specific considerations made by researchers are intended to determine and select sources/ informants who are considered to know the most about the researched social situation. The key informants in this study are people who have a strategic position that understands the learning model that is applied to office administration training at BBPLK Semarang, such as instructors and training organizers. Through those key informants, advice and support can be sought for access to other sources of evidence that can support the research focus. That access can be obtained in the form of information from trainees and the FMD team.

The source of the data in this study is primary data which is obtained from the information on training, training instructors, training participants, FMD Team. The secondary data is additional data which is used to complete data. It is obtained through documentation or literature by reviewing scientific books related to learning models and work readiness. Data collection techniques used are observation, interviews and documentation.

The validity of the data in this study uses data/source triangulation and method triangulation. Researchers use source triangulation, that is, comparing and checking both the degree of trust of information which obtained by using guidelines that have been arranged or prepared for data collection. Method triangulation used is interview, observation and documentation. The data analysis used in this study takes place with the data collection process. The analysis consists of three activities, those are data reduction, data presentation and withdrawal.

\section{RESULTS AND DISCUSSION}

The implementation of Learning Model in Office Administration Training

According to (Joyce, B., \& Weil, M, 2011) the learning model has five components, those are syntax (syntax), social system, reaction principle, support system, instructional impact and companion impact. In implementing the learning model, office administration training cannot be separated from those five components.

The operational steps of office administration learning include three main steps of activities namely preliminary activities, core activities and closing activities. This is relevant to the opinion (Rifa'i, 2009) that the steps in the adult learning process generally include preliminary activities, core activities and closing activities. However, in each step there are activities carried out by the instructor together with the participants to achieve the competencies that have been set.

Preliminary activities include: checking or examining attendance. By these activities, the instructor can get to know all the participants and bridge the instructor to attract the attention of participants so that participants can devote their attention to the learning that will be carried out. These results are relevant to the learning step of information processing 
models in which the theory by (Joyce, B., \& Weil, M, 2011), stated that the first step in learning is to take action to attract the attention of students. The second activity, which was carried out by the instructors was to create a conducive learning climate, the learning climate in office administration training included classrooms that were far from the crowds, air-conditioned classrooms, adequate classroom lighting, the presence of picket teams, and adequate learning facilities. Researcher's findings are supported by the results of the research from (Mohamed \& Schutte, 2013) that was: "The study revealed that a learning climate can be created in different types of organizations through organizational, group and individual drivers. It further revealed that the strategy in creating a climate of learning should be aligned with the organization's structure, culture and goals"

The third activity, in the preliminary stage, the facilitator fosters participants' learning motivation. The results of the study (Omar \& Noordin, 2013) stated that "motivation can be defined plainly as the process whereby goaldirected activity". Motivation is very important in teaching and learning activities, because the motivation motivated learning and on the contrary lack of motivation will weaken the spirit of learning.

Based on the results of the study, the instructor provides motivation to the training participants before learning begins and on the sidelines of the process of learning activities. The motivation is given in the way the instructor provides an overview of the working world, tells about some alumni who have yield to get a job in a company and gives encouragement to the trainees so that they are really take part in the training, then, after completing the training they can get a job in accordance with their competence. The results of this study are supported by the existence of research from (Waluyo \& Desamawati, 2015), which stated that motivation is an important factor in influencing learning outcomes. Through the andragogy approach, it can increase the motivation of students in completing the existing tasks. Then reinforced the results of research from (Sudarma \& Sakdiyah, 2007), the results of his research shows that there is a positive influence between motivation on student achievement.

Fourth, the provision of learning references, the next activity carried out by the instructor is to make a conceptual connection by giving questions about the material that was submitted in the previous day, this was done to stimulate the participants to keep in mind the material given at the last meeting. These findings are relevant to the learning step of information processing model from the theory of (Joyce, B., \& Weil, M, 2011) that one step of this model is to stimulate the learners to begin a learning activities.

Core activities are the main activities in the learning process. Office administration learning is held every Monday to Saturday, from Monday to Thursday the learning process starts at 07:45 and end at 15:00, Friday is end at 11:45, then for Saturday learning starts at the same time at 07:45 and finishes at 14.15. The first step in the core activity is the instructor delivers the material in detail to the trainees. In learning process, the instructor uses a participant-centered approach. This means that the learning system in office administration places the trainee as the active learners subjects. These findings are supported by the results of the research from (Antika, 2014), that educators believe that the learning process will run optimally if the students are actively involved in it. The research conducted by (Buditama, 2017) obtained results "The studentcentered teaching guide can enhanced the students' writing skill in the basic grammar".

The results of the above research are relevant to the theory of (Sunhaji, 2013), which states that one of the principles of adult learning is active learning, this principle requires participants will study hard if they are actively involved in the training process, as John Dewy said Learning by doing. Another theory that supports the results of this study is the theory of (Dimyanti \& Mudjiono, 2009), that the principle in learning one of which is activity, teaching is the process of guiding the learning experience. The method used by 
instructors in delivering material is lectures, question and answer, simulations and demonstrations/ exercises. The use of this method is adjusted to the training material. These findings are supported by the theory of (Nurhalim, 2011), that learning methods which commonly used in training include: exercises, lectures, and question and answer methods.

In the office administration training study, instructors use several media that can support the implementation of learning, those media include slide/ power point media, whiteboards, module handouts, and flip charts. These media are used based on the need to attract students' attention and facilitate them in understanding the material delivered by the instructor. The results of this study are relevant to the theory of (Sutarto, 2013) that there are several benefits by using the media in the implementation of learning, including it will attract students' attention, allows more concrete and non-verbalistic learning variations, the materials delivered by the instructor will be easily understood, and the learning media can overcome the limitations of senses, space and time.

The second step is at the end of each indicator of performance's discussion, the instructor gives the same opportunity to all participants to ask if there is a material that has not been understood, if there is a participant who will asks, the instructor first gives the other participants the opportunity to answer, then the instructor gives the correction of the answer. This finding is supported by the theory of information processing learning step models from (Joyce, B., \& Weil, M, 2011), that educators provide opportunities for students to ask and answer based on their experiences, then provide a feedback on the behavior shown by the students.

The closing activity of learning is as important as opening learning. The activity carried out by the instructor at the closing stage is to review the training material that has been given by giving questions to the participants, this is done in an effort to find out how far the participants have understood the material given by the instructor. The next activity is evaluation. Evaluation is an important activity to find out whether a predetermined goal can be achieved. Learning process evaluation is carried out by the instructor through the trainee with a predetermined assessment system in accordance with the curriculum that has been planned from the beginning. The evaluation applied by the instructor is a gradual evaluation, this evaluation is done by every performance indicator. The results of this study are relevant to personal model theory from (Joyce, B., \& Weil, M, 2011) that stated at the end of each section the educator does an assessment.

The social system, is the atmosphere and norms that apply in learning process. The social system in a learning model is the interaction that occurs between the learning actors (Joyce, B., \& Weil, M, 2011) The atmosphere of learning in office administration training is created casually but it is directed at the real world of work where trainees are accustomed to discipline. The learning atmosphere that created by the instructor is a free or open atmosphere, in which the instructor gives a freedom to the trainees for asking questions and giving opinions in accordance with the objectives of the office administration learning process. This is relevant to the principle of adult learning theory from (Rifa'i, 2009) that stated that the condition of adult learning environment is indicated by pleasant physical conditions, mutual respect, trust, mutual assistance, freedom of expression, and agreeing to differences. In addition it is supported by the theory of (Sutarto, 2013) which states that, in carrying out the process of implementing learning, non-formal education units have a different climate or atmosphere, one of the atmosphere is an open atmosphere, which is characterized by characteristics, namely the atmosphere full of enthusiasm, life and moving towards the goal, able to provide satisfaction needs, and the authenticity of the behavior that occurs among all personal components.

In the office administration training, there are some rules to arrange learning activities so as it creates a safe and peaceful 
atmosphere and can create a conducive learning situation. The existence of the rules can train the discipline of the trainees. Besides to the rules, the instructor also applied punishment and reward in the office administration training. Both of these are to strengthen positive behavior and weaken negative behavior. The results of this study are relevant to behavioral modification learning model theory from (Joyce, B., \& Weil, M, 2011) which stated that this model is also known as a behavior modification model. As an illustration of the model of behavior modification in learning which is the provision of reward and punishment for students by educators can affect the state of behavior of students.

The principle of reaction describes how teachers/ tutors should view, treat, and respond to students/ citizens (Joyce, B., \& Weil, M, 2011). The participants who take part in office administration training are adults. Therefore in learning process, the instructors must also treat the trainees like adults. Instructors in learning do not dominate as in pedagogy learning, in this case the instructor facilitates and guides the participants more. Because the trainee come from heterogeneous educational settings, the instructor remains to keep being fair and does not discriminate participants' abilities. In the teaching and learning process the instructor uses the brainstorming method, so that the trainees can share their knowledge and experience between one another. In addition the instructor appreciates every opinion given by the participant, without any blame for this because it can support/ encourage them to be brave and accustomed to expressing opinions in front of a crowd. The results of this study are relevant to the principles of adult learning theory from (Rifa'i, 2009), which stated that the importance of feeling in adult learning by which the instructor should have responses that there is not important distinction between cognitive and affective aspects of learning. Educator's behavior should show affections, respect, appreciate, and support to the participants.
Supports system are any means, materials, tools, or learning environment that supports the implementation of the learning model (Joyce, B., \& Weil, M, 2011). Supporting factors in the implementation of the learning model in office administration training include human resources, training participants, facilities and infrastructure and learning environment.

Human Resources (HR), BBPLK Semarang in its operational activities supported by Human Resources (HR) who have competencies in accordance with their fields. The existing human resources at BBPLK Semarang consist of structural, general, and certain functionalities. The learning process of office administration training is supported by 29 experienced instructors who have the competence in accordance with their field of expertise and have completed the certain basic training for prospective instructors. The instructor is one of the success key in achieving the ultimate goal of the training, by the presence of competent and experienced instructors, he can help trainees in carrying out their learning activities well.

Learners are the most important element in learning process, they can be a supporting factor and even can be an inhibiting factor in the learning process. Based on the results of the study, the majority of the trainee were active and had a high motivation in participating those office administration training lessons. This can be a proponent factor in the implementation of the learning model.

The facilities and infrastructure which contained in BBPLK Semarang are adequate. The field Findings showed that the facilities that support the implementation of office administration learning models include: practical equipment, learning media, and public facilities. While the supporting infrastructure includes: classrooms, library rooms, office administration's lab, computer's lab, 3in1 small shop, Competency Test Place (TUK), and hall.

The existence of a learning environment can be a supporting factor and can even be an inhibiting factor in the implementation of 
learning, absolutely this depends on the conditions of the learning environment. Based on the results of the study, BBPLK Semarang is in the city center that is easily access by public transportation. The theory and practice room which equipped by facilities to support learning is far from the highway, so there is no noise that can disturb the learning process. By means of these environmental conditions, it makes the participants comfortable in joining the learning process, without any sense of pressure or compulsion, so that the learning process can run conducively.

Instructional effects are the learning outcomes that are directly achieved by facing the students to the expected goals (Joyce, B., \& Weil, M, 2011). Learning outcomes which is obtained directly from office administration learning is that the trainees gain knowledge in the field of office administration, especially for 29 participants who have been declared competent, they have mastered all the material which contained in 14 competency units. In addition they have the skills in using office equipment and accordance with those stated in soft skills training.

Companion effects (nurturant effects) are the other learning outcomes produced by the interaction of teaching and learning as a result of the creation of a learning atmosphere that is directly experienced by students (Joyce, B., \& Weil, M, 2011). The result of this companion effect is in the form of an attitude changing of the participants. One of the attitudinal changes is participant discipline, it is reflected in the fewer trainees who are late during the morning ceremony. Besides the discipline, the other impact is politeness, this is seen when the trainee asking questions or in answering questions from the instructor, they are polite and respect each other.

The politeness was also reflected when they met with the instructor outside of the learning hours, they gave a smile and greeted him . Neatness can be seen from the way the participants dressed, they use complete uniforms in accordance with existing regulations. Then the other learning outcomes generated in the interaction of teaching and learning as a result of the creation of a learning atmosphere that is experienced directly by students in terms of tidiness.

Referring to learning models theories from (Joyce, B., \& Weil, M, 2011), and based on the description of the learning syntax, social system, reaction principle, support system, instructional impact and companion impact on the above office administration learning, it can be concluded that, the learning model implemented by the instructor refers to the information processing learning model, personal model and behavior modification model. The instructor collaborates those three models in office administration learning to obtain effective and efficient learning outcomes. In the application of those three models, the instructor is guided by the principles of adult learning, so that it can be obtained the prospective workers who are competent and ready to work in accordance with market demands.

\section{Work Readiness of Training Participants}

According to (Joyce, B., \& Weil, M, 2011), students' personal development is needed to support the quality of graduates.Besides that the participants are equipped with knowledge, BBPLK Semarang prepared several activities that could support the work readiness of them before entering the workforce. This is relevant to the theory of (Anoraga, 2009), which stared that the preparation in entering the workforce requires a careful readiness. The prepared activities by BBPLK Semarang, in an effort to prepare participants to enter the workforce, are the orientation activities for new participants, which contain some material provided for training participants in competing in the job market. The material consists of sofskill and character building.

Character building materials includes physical, mental, and discipline. Then soft skills include applying self-concept to achieve success, managing yourself to improve work ethic, applying 5S (Smile, greeting, regards, courteous, polite) at work place, improving the quality of appearance and professional 
attitude, preparing job applications and interview tests, managing finances personal, and 3in1 kiosk socialization. Giving those material on softskill and character building is aimed to support the readiness of trainees in entering the workforce. As the purpose of the training is not only to equip participants with knowledge and skills, but also to construct the readiness of the trainees so that they will be ready to join the job market after they finished training.

The physical readiness which is prepared by the BBPLK for the trainees was through the morning ceremony. If there are participants who are late in attending the ceremony, they will be given a sanction to make them wary. Those sanctions are more focused on their physique. The trainees' mental readiness is fostered by offering the rotating responsibilities to lead the morning ceremony and be trained to discipline. Besides that it is also supported by a theory from (Anoraga, 2009), that the characteristic of people who have work readiness is discipline, which they always obey the rules.

Emotional readiness prepared by BBPLK Semarang for the training participants is the provision of $5 \mathrm{~S}$ material (smile, greetings, greetings, courtesy, courtesy), and the participants are also accustomed to work together. Those can help the participants to prepare their emotional and social readiness, so that when they are in the work world, they are able to socialize and communicate one another well.

According to (Anoraga, 2009), the characteristics of work readiness include: having motivation, having sincerity or seriousness, having a sufficient skills, and discipline. Based on several efforts made by BBPLK Semarang to prepare trainees to enter the workforce, the results showed that from 32 participants who attended office administration training, 29 people were declared competent in a job, soft skills, and supporting training, which is character building. By these results, it can be concluded that 29 office administration trainees have had work readiness to compete in the work world.

\section{CONCLUSION}

The conclusions of the study regarding the implementation of learning models and work readiness of the participants after completing office administration training are the learning models which were done in office administration training refers to information processing models, personal models and behavioral modification models. The implementation of those three models includes: learning syntax, social system, reaction principle, support system, instructional impact and companion impact. Its implementation was guided by the principle of adult learning.

Participants' work readiness is fostered through job training activities which include 14 competency units, soft skill activities, and character building. Based on several activities carried out by BBPLK Semarang to prepare the trainees to move into the workforce, it is obtained that 32 participants who attended office administration training, 29 of them were declared competent in job training, soft skills training and supporting training, namely character building. By these results it can be concluded that 29 office administration trainees have had work readiness to compete in the work field. 


\section{REFERENCES}

Anoraga, P. (2009). Work Psychology. Jakarta: Rineka Cipta.

Antika, R. R. (2014). Student Centered Based Learning Process (Descriptive Study in SMP Baitul Izzah. Bioculture Journal, 3(1).

Buditama, M. (2017). Student-centered learning approach in teaching basic grammar. Journal on English as a Foreign Language, 7(2).

Bungin, Burhan. (2007). Qualitative Research: Communication, Economics, Public Policy, and Other Social Sciences. Jakarta: Kencana.

Central Statistics Agency. 2017. Official News Statistics No. 38/05 / Th. XVII, https://www.bps.go.id/linkTabelStatis /view/id/972. (Retrieved on 10 November 2017).

De Palo, V., Limone, P., Monacis, L., Ceglie, F., \& Sinatra, M. (2018). Enhancing elearning in old age. Australian Journal of Adult Learning, 58(1).

Dimyanti, \& Mudjiono. (2009). Learning and Learning Process. Jakarta: Rineka Cipta.

Fernandes, A. A. R., \& Taba, I. M. (2018). Welding technology as the moderation variable in the relationships between government policy and quality of human resources and workforce competitiveness. Journal of Science and Technology Policy Management.

Ganiron Jr, T. U. (2013). Application of Accelerated Learning in Teaching Environmental Control System in Qassim University. International Journal of Education and Learning, 2(2).

Hidayat, D. (2016). Participatory Learning Model in Improving the Results of NonFormal Education Programs in Karawang. Journal of Nonformal Education, 2(1).

Joyce, B., \& Weil, M. (2011). Models of Teaching (Teaching Models)(Eighth Edision). Translation by Ahmad Fawaid \& Ateilla Mirza. Yogyakarta: Pustaka Pelajar.

Kamil, M. (2012). Education and Training Model. Bandung: Alfabeta.

Mohamed Hoosen Carrim, N., \& Schutte Basson, J. (2013). Creating a learning climate: a South African study. The Learning Organization, 20(1).

Nurhalim, K. (2011). Non Formal Education Learning Strategies. Semarang: Unnes FIP School Education Department.
Omar, S., Jain, J., \& Noordin, F. (2013). Motivation in Learning and Happiness among the Low Science Achievers of a Polytechnic Institution: An Exploratory Study. Procedia-Social and Behavioral Sciences, 90, 702-711.

Polapa, I. (2015). Development of Andragogical Participatory Learning Models to Improve Learning Outcomes of Citizens Learning. Irfani, 11 (1).

RI Minister of Manpower and Transmigration Regulation No. 11 of 2013 concerning The Guidelines for Implementation of National Job Training Systems in Regions

Rifa'i, A. (2009). Adult Learning Design. Semarang: UNNES Press.

Ruhana, I. (2012). Quality Development of Human Resources VS Global Competitiveness. Profit (Journal of Business Administration), 6(1).

Sudarma, K., \& Sakdiyah, E. M. (2007). The influence of Student Motivation, Discipline and Participation in Learning on Accounting Learning Achievement. Educational Dynamics, 2(2).

Sunhaji, S. (2013). Adult Education Concept. Journal of Education, 1(1).

Sutarto, J. (2013). Training Management. Yogyakarta: Deepublish.

Uno, H. B. (2009). The Learning Model Creates a Process Creative and Effective Teaching. Jakarta: Bumi Aksara.

Waluyo, Y. T., \& Desamawati, L. (2015). The Role of Tutors in Increasing Students' Learning Motivation Through Andragogy Approaches in Banjarnegara Detention Centers. Journal of Non Formal Education and Community Empowerment, 4(1).

Wardani, P. Y. (2012). Internship Learning Model (Study of Metal Craftsmen at Sentra Home Metal Industries Kejambon, Tegal. Journal of Nonformal Education and Community Empowerment, 1(2).

Widodo, H. (2016). Potret Pendidikan di Indonesia dan Kesiapannya dalam Menghadapi Masyarakat Ekonomi Asia (MEA). Cendekia: Jurnal Kependidikan Dan Kemasyarakatan, 13(2).

Yuriani, Y., Marwanti, M., Komariah, K., Ekawatiningsih, P., \& Santosa, E. (2012). Pengembangan model pembelajaran kursus kewirausahaan melalui kerja sama dunia usaha dan dunia industri. Jurnal Kependidikan: Penelitian Inovasi Pembelajaran, 42(1). 